\title{
PENGARUH ROE DAN EPS TERHADAP HARGA SAHAM PADA PERUSAHAAN PEMBANGUNAN TAHUN 2012-2017 YANG TERDAFTAR DI BEI
}

\author{
Shindi devia areza rahmadini \\ Fakultas ekonomi islam batik Surakarta \\ Shindirahmadini77@gmail.com
}

\begin{abstract}
Return on Equity (ROE) is to compare net income after tax with total equity. Earning Per Share Ratio (EPS) is a ratio used to determine the amount of money generated from each common stock. This research aims to find earnings per share and return on equity development companies in 2012-2017 registered in bei.population of all development companies registered in bei in 2012-2017 namely 16 companies, from the participation obtained data samples of 11 companies that fit the sampling criteria. Multiple linear regression. The results of the study found that ROE has no effect on stock prices and EPS supports stock prices.
\end{abstract}

Keywords: Roe, EPS, Stock Price

\begin{abstract}
Abstrak
Return on Equity (ROE) adalah dengan membandingkan laba bersih setelah pajak dengan total ekuitas Rasio Earning Per Share (EPS) merupakan rasio yang digunakan untuk menunjukkan jumlah uang yang dihasilkan dari setiap lembar saham biasa.Penelitian ini bertujuan untuk mengetahui earning per share dan return on equity pada perusahaan pembangunan tahun 2012-2017 yang terdaftar di bei.populasi seluruh perusahaan pembangunan yang terdaftar di bei tahun 2012-2017 yaitu 16 perusahaan ,dari populasi tersebut di peroleh sampel data sebanyak 11 perusahaan yang sesuai kriteria sampling .dalam penelitian ini mengunakan metode analisis regresi linier berganda.hasil penelitian diperoleh bahwa ROE tidak bepengaruh terhadap harga saham dan EPS berpengaruh terhadap harga saham.
\end{abstract}

Kata kunci : Roe,Eps,Harga,Saham.

\section{PENDAHULUAN}

Perekonomian di Indonesia saat ini sangat berkembang pesat salah satunya adalah perkembangan pasar modal hal tersebut dikarenakan minatnya publik terhadap pasar modal dengan begitu perusahaan yang terdaftar di pasar modal juga mengalamai peningkatan dukungan pemerintah melalui kebijakan investasi kegiatan ini dapat diharapkan untuk mendapatkan keuntungan bagi para pelaku dalam menanamkan modal saham diperusahaan tersebut.perusahaan go public mempunyai tujuan yaitu dengan memaksimalkan keuntungan para pemegang sahamnya,tetapi keadaan ini tidak mudah dikarenakan adanya fluktuasi terhadap harga saham yang setiap waktu harga saham dapat berubah-ubah.

Laporan keuangan sangat di perlukan oleh investor untuk mengetahui kondisi keuangan perusahaan tersebut dalam periode tertu dengan begitu investor akan dapat membuat keputusan untuk tetap menanamkan modalnya atau tidak (tetapi tinggi rendahnya suat harga saham di perusahaan dipengaruhi oleh banya faktor seperti kinerja perusahaan,tingkat suku bunga, deviden, penawaran, permintaan dan kondisi keuangan (Nurhasanah, 2013). Salah satu alat analisi harga saham ini dengan menggunakan analisis fundamental perusahaan melalui analisis rasio keuangan.

Tujuan penelitian ini adalah untuk menganalisis dan mengatahui bagaimana pengaruh roe dan eps terhadap harga saham. Manfaat dari penelitian ini adalah untuk dapat dijadikan referensi kepada penelitian selanjutnya tentang pengaruh Roe dan Eps terhadap harga saham.

\section{TINJAUAN PUSTAKA}

Penelitian ini menggunakan teori signaling. Teori signaling ini yang banyak dibutuhkan oleh investor karena untuk mempertimbangkan investor untuk menanamkan saham atau tidak di perusahaan yang bersangkutan dengan adanya teori pensinyalan ini maka umumnya pasar akan lebih mudah menerima informasi tersebut untuk mengetahui suatu kejadian 
yang akan mempengaruhi nilai perusahaan terhadap harga saham.

1. Harga Saham

Harga saham menentukan kekayaan pemegang saham. Maksimalisasi kekayaan pemegang saham diterjemahkan menjadi maksimalkan harga saham perusahaan. Harga saham pada satu waktu tertentu akan bergantung pada arus kas yang diharapkan diterima di masa depan oleh investor "ratarata" jika investor membeli saham.

2. ROE (Return On Equity)

Return On Equity yaitu mengukur kemampuan perusahaan dalam memperoleh laba yang tersedia bagi pemegang saham perusahaan. Rasio ini dipengaruhi oleh besar dan kecilnya utang perusahaan, jika proporsi utang semakin besar maka rasio ini akan semakin besar pula.

3. EPS (Earning Per Share)

EPS atau laba bersih per saham adalah Pendapatan bersih perusahaan selama setahun dibagi dengan jumlah rata-rata lembar saham yang beredar, dengan pendapatan bersih tersebut dikurangi dengan saham preferen yang diperhitungkan untuk tahun tersebut.

\section{PENELITIAN SEBELUMNYA}

Hasil penelitian ini berbeda dengan penelitian yang dilakukan oleh (Sari et al., 2016) menunjukkan bahwa variabel ROE tidak berpengaruh secara terhadap harga saham. Variabel EPS menunjukkan bahwa eps berpengaruh positif terhadap harga saham perusahaan. EPS positif mempengaruhi harga saham berarti semakin tinggi EPS lebih mahal harga satu saham.

\section{Kerangka berpikir}

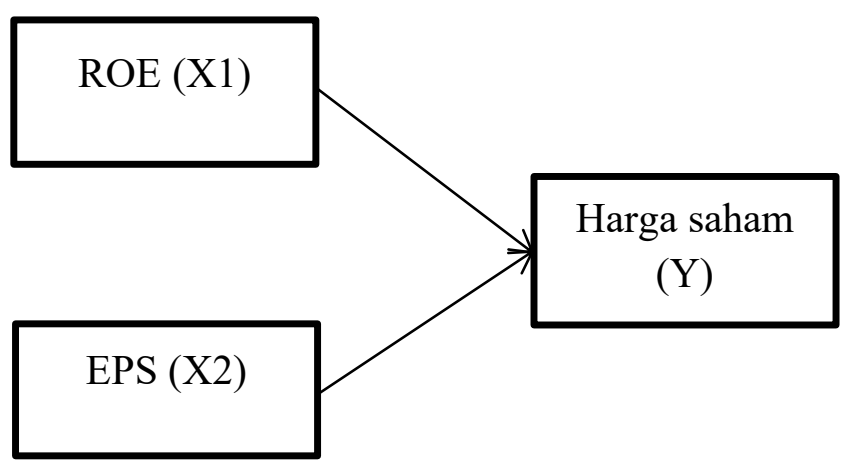

Hipotesis

\section{Gambar 1 kerangka berpikir}

1. Roe
Roe atau rentabilitas adalah rasio yang digunakan untur mengukur laba bersih setelah pajak dengan modal sendiri rasio ini menunjukan bahwa jika perusahaan mampu untuk memberikan laba dan ekuitas dan jika ROE mampu meningkat dengan begitu investor akan tertarik menanamkan sahmnya di perusahaan tersebut dengan begitu akan meningkatkan harga saham.penelitian oleh (Octavianty \& Apprilia, 2014) menunjukkan bahwa ROE berpengaruh positif terhadap harga saham.

H1 : ROE berpengaruh positif terhadap harga saham.

2. Eps

Pemberian keuntungan atau laba bersih kepada pemegang saham atas lembar saham yang dimiliki dengan begitu semakin tinggi nilai eps makan akan semakin tinggi laba yanga akan diterima oleh pemegang saham.

Metode

H2 : Eps Berpengaruh Positif Terhadap Harga Saham.

penelitian ini menggunakan penelitian deskriptif kuantitatif, variabel independennya adalaha ROE (X1),EPS (X2) sedangakan untuk varibel dependenya adalaha harga saham (Y).sumber data yang digunakan dalam penelitaian menggunakan data sekunder,sedangkan instrument penelitian dengan cara dokumentansi (mengambil data laporan keuangan perusahaan).populasi yang digunakan dalam penelitian ini perusahaan pembangunan yang terdaftar di bei tahun 2012-2017,sedangkan untuk sampel penelitian menggunakan metode purposive sampling.metode analisis yang digunakan dalam penelitian ini adalah metode analisi linier berganda.

Tabel 1.

kriteria pemilihan sampel

\begin{tabular}{|l|l|}
\hline KRITERIA & JUMLAH \\
\hline $\begin{array}{l}\text { Peruhaan sub sector pembangunan } \\
\text { yang terdaftar di bei tahun2012- } \\
2017\end{array}$ & 16 \\
\hline $\begin{array}{l}\text { Perusahaan sub sector } \\
\text { pembangunaan yang tidak } \\
\text { melaporkan laporan keuangan } \\
\text { periode 2012-2017 }\end{array}$ & $(5)$ \\
\hline \multicolumn{1}{|c|}{ Jumlah perusahaan } & 11 \\
\hline $\begin{array}{l}\text { Data penelitian selama periode } \\
\text { 2012-2017 }\end{array}$ & 66 \\
\hline Data outlier & $(7)$ \\
\hline Jumlah sampel dalam penelitian & 59 \\
\hline
\end{tabular}


Tabel 2.

PENGUKURAN VARIABEL PENELITIAN

\begin{tabular}{|c|c|c|}
\hline 1 & $\begin{array}{l}\text { Harga } \\
\text { saham }\end{array}$ & $\begin{array}{l}\text { Closing price periode } 2012-2017 \text { pada perusahaan } \\
\text { pembangunan yang terdaftar di bursa efek Indonesia } \\
\text { periode } 2012-2017 \\
\text { Sunariyah }(2011: 124)\end{array}$ \\
\hline 2 & Roe & $\begin{array}{l}\mathrm{ROE}=\frac{\text { earning after tax }}{\text { total equity }} \times 100 \% \\
\text { Kasmir }(2014: 204)\end{array}$ \\
\hline 3 & Eps & $\begin{array}{l}\text { EPS }=\frac{\text { eat }}{\text { jumlah lembar saham }} \\
\text { Sutrisno }(2013: 230)\end{array}$ \\
\hline
\end{tabular}

Dari Hasil Pengujian Yang Telah Dilakukan Dengan Menggunakan Uji KolmogorovSminorv Apabila Sig $>0,05$ Maka Data Berdistribusi Normal

a. Analisis Statistik Deskriptif
Dari hasil uji statistik deskriptif Roe dan Eps,terhadap harga saham seperti table 2 di bawah ini

Tabel 3.

HASIL UJI STATISTIK DESKRIPTIF

\begin{tabular}{llllll}
\hline & $\begin{array}{l}\text { Total } \\
\text { sampel }\end{array}$ & $\begin{array}{l}\text { Nilai } \\
\text { minimum }\end{array}$ & $\begin{array}{l}\text { Nilai } \\
\text { maksimum }\end{array}$ & $\begin{array}{l}\text { Nilai rata- } \\
\text { rata }\end{array}$ & $\begin{array}{l}\text { Standar } \\
\text { deviasi }\end{array}$ \\
\hline Roe & 59 & .43 & 44.23 & 16.1678 & 9.35656 \\
Eps & 59 & .85 & 225.54 & 84.5608 & 56.54000 \\
Harga saham & 59 & 7.62 & 62.25 & 34.2638 & 15.11817 \\
\hline
\end{tabular}




\section{Uji asumsi klasik}

\begin{tabular}{|c|c|c|c|c|}
\hline \multicolumn{2}{|c|}{ Variabel } & \multicolumn{2}{|c|}{$\begin{array}{l}\text { Sig. } \\
(2- \\
\text { tailed })\end{array}$} & Standar \\
\hline \multicolumn{2}{|c|}{ Roe } & \multicolumn{2}{|c|}{.682} & $>0,05$ \\
\hline \multicolumn{2}{|c|}{ Eps } & \multicolumn{2}{|c|}{1.000} & $>0,05$ \\
\hline \multicolumn{5}{|c|}{$\begin{array}{l}\text { Ada } 4 \text { test yang digunakan dalam untuk } \\
\text { menjelaskan tentang pengaruh harga saham: } \\
\text { 1. Uji normalitas } \\
\text { Dari hasil penguji Kolmogorov- } \\
\text { smirnov dengan tariff signifikan }(\alpha) \\
0,05 \text { pada tabel } 4 \text { menunjukan bahwa } \\
\text { besar nilai asymp.sig (2-tailed) adalah } \\
0,200 . \text { karena signifikan lebih dari } 0,05 \\
(0,0200>0,05) \text { maka data terdistribusi } \\
\text { normal. }\end{array}$} \\
\hline \multicolumn{5}{|c|}{$\begin{array}{c}\text { Tabel } 4 \\
\text { HASIL UJI NORMALITAS } \\
\end{array}$} \\
\hline Variabel & $\mathrm{N}$ & $\begin{array}{l}\text { Asymp.si } \\
\mathrm{g} \\
\text { (2-tailed) }\end{array}$ & $\begin{array}{l}\text { Standa } \\
\text { r }\end{array}$ & Keterangan \\
\hline $\begin{array}{l}\text { Unstandardi } \\
\text { zed residual }\end{array}$ & & 0,200 & $>0,05$ & $\begin{array}{l}\text { Data } \\
\text { terdistribus } \\
\text { i normal }\end{array}$ \\
\hline
\end{tabular}

2. Uji multikolonieritas

Dari hasil uji multikolonearitas pada tabel 5 diketahui bahwa nilai tolerance pada vaiabel tersebut lebih dari 0,10 (toleransi $>0,10$ ) dan VIF kurang dari 10(VIF <10) dapat disimpulkan bahwa tidak terjadi multikolonearits.

\section{PEMBAHASAN}

Berdasarkan hasil uji hipotesis diatas dijelaskan sebagai berikut :

1. Hasil pengujian ROE (X1) tidak berpengaruh terhadap haga saham diarena perusahaan tidak mendapatkan keuntungan dari penggunaan efektivitas modal maka nilai perusahaan yang ditunjukkan dengan harga saham tidak mengalami peningkatan penelitian ini sejalan degan penelitian oleh Talamati (2015),Pangemanan (2015) dan sari (2016),suhermin(2016).

2. Hasil pengujian EPS (x2) berpengaruh terhadap harga saham Jika jumlah uang yang

\author{
Keterangan \\ Tidak terjadi \\ heterokedasititas \\ Tidak terjadi \\ heterokedasititas
}

3. dihasilkan perusahaan meningkat maka nilai perusahaan yang ditunjukkan dengan harga saham akan meningkat pula penelitian Ini sejalan dengan penelitian Al- Dini et al. (2011), Placido (2012) dan Uddin et al. (2013).

\section{KESIMPULAN DAN SARAN}

Dari hasil penelitian yang telah dilakukan dapat disimpulkan secara parsial bahwa roe,eps tidak berpengaruh ROE tidak berpengaruh terhadap harga saham sedangkan untuk EPS berpengaruh terhadap haga saham.untuk pengaruh secara silmutan roe dan eps tidak berpengaruh terhadap harga saham pada perusahaan pembangunan yang tedaftar di BEI tahun 2012-2017. . Keterbatsan penelitian : 1. Hasil penelitian ini tidak dapat di generalisir terhadap penelitian serupa karena penelitian ini hanya dilakukan pada perusahaan pembangunan. 2. Periode penelitian yang relatif panjang (2012-2017). Berdasarkan pembahasan dan hasil penelitian, maka saran yang dapat diajukan adalah: 1.sebaiknya meneliti variabel lain sebagai variabel yang diduga dapat mempengaruhi harga saham seperti varibel mikro ekonomi (Debt to Equity Ratio (DER), Net Profit Margin (NPM), Price to Equity Ratio (PER) dan makro ekonomi (Inflasi, BI Rate, Dollar, Jumlah Uang Beredar) serta periode pengamatan yang berbeda sehingga dapat melihat fenomena dan perubahan harga saham yang terjadi.

\section{DAFTAR PUSTAKA}

Nurhasanah, R. (2013). Pengaruh Return On Asset (ROA), Return On Equity (ROE), dan Earning Per Share (EPS) terhadap Harga Saham (Survey pada Perusahaan LQ45 yang Terdaftar di Bursa Efek Indonesia Periode 2007 - 2011). Skripsi Pada Jurusan Akuntansi Fakultas Ekonomi Universitas.

Octavianty, E., \& Apprilia, F. (2014). Pengaruh EPS, BVS, ROE, DER terhadap Harga 
Saham Perusahaan BUMN yang terdaftar di BEI. Jurnal Ilmiah Manajemen dan

Akuntansi Fakultas Ekonomi. JIMAFE, Vol

2.

Sari, Indra, Y., \& Suhermin. (2016). Pengaruh

Faktor-Faktor Fundamental Terhadap

Harga Saham pada Perusahaan

Telekomunikasi. Jurnal Ilmu Dan Riset

Manajemen, Vol 5 No 7. 